\title{
Binding and ingestion of human lactoferrin by mouse alveolar macrophages ${ }^{1}$
}

\author{
BERND MARKOWETZ, ${ }^{2}$ JACQUES L VAN SNICK, ${ }^{3}$ AND PIERRE L MASSON
}

From the Unit of Experimental Medicine, International Institute of Cellular and Molecular Pathology, Université Catholique de Louvain, B-1200, Brussels, Belgium

ABSTRACT ${ }^{59} \mathrm{Fe}$-labelled human lactoferrin was found to be preferentially ingested by mouse alveolar macrophages (MAM) when compared to ${ }^{59} \mathrm{Fe}$-labelled human transferrin. The cells bound and ingested ${ }^{125} \mathrm{I}$-labelled iron-saturated and iron-free lactoferrin. The latter was digested faster ( $t \frac{1}{2}=5 \cdot 8$ hours), however, than the iron-saturated compound ( $t \frac{1}{2}=10.5$ hours).

The constant elimination of the Fe-lactoferrin complex by alveolar macrophages could enhance the bacteriostatic effect of lactoferrin in the pulmonary secretions.

Lactoferrin (Lf), the iron-binding protein of bronchial and other external secretions, inhibits the growth of various bacteria by depriving them of iron (Masson et al, 1966a; Oram and Reiter, 1968; Bullen et al, 1972). Recently we have shown that Lf has a particular affinity for peritoneal macrophages that possess a specific receptor for this protein (Van Snick and Masson, 1976). After binding to the membrane of macrophages the protein is ingested by the cells where it persists for several hours (Van Snick et al, 1977). Should such a mechanism operate in the airways it could enhance the bacteriostatic effect of Lf by constantly removing the iron-Lf complex. We have therefore examined alveolar macrophages to see whether they display the same affinity for Lf as peritoneal macrophages.

\section{Materials and methods}

Ideally, a study of the interaction of proteins and cells should be done with homologous material. The difficulty of obtaining sufficient amounts of both proteins and cells from the same species imposed on us the heterologous system of human Lf and mouse cells. Such a heterologous system was

'Supported by grant No 3.4529-78 from the Fonds de la Recherche Scientifique Médicale, Brussels, and a grant from the Cancer Research Fund of the Caisse Générale d'Epargne et de Retraite, Brussels.

'B Markowetz is from Lungenklinik Heckeshorn, 1 Berlin 39 WestStipendiat der Deutschen Forschungsgemeinschaft.

"J L Van Snick is "aspirant" at the Fonds National de la Recherche Scientifique, Brussels. found suitable with mouse peritoneal macrophages (Van Snick and Masson, 1976; Van Snick et al, 1977).

\section{Cells}

Mouse alveolar macrophages (MAM) were collected from lungs of unstimulated female mice of the outbred strain NMRI by 10 washings of the pulmonary tract with $1 \mathrm{ml}$ of $0.9 \% \mathrm{NaCl}$ and recovered by centrifugation at $200 \mathrm{~g}$ for $10 \mathrm{~min}$ at $4^{\circ} \mathrm{C}$. The mean yield was $2 \times 10^{5}$ mononuclear cells per mouse. After resuspension in basal medium Eagle (BME) supplemented with $25 \%$ heat-inactivated newborn calf serum (FCS), penicillin $(50 \mathrm{U} / \mathrm{ml})$, and streptomycin $(50 \mu \mathrm{g} / \mathrm{ml})$, the cells were seeded in Linbro tissue culture plates and incubated for $1 \mathrm{~h}$ at $37^{\circ} \mathrm{C}$ in a $5 \%$ $\mathrm{CO}_{2}$ atmosphere. The adherent alveolar macrophages were then washed twice with BME without serum to remove lymphocytes and erythrocytes, and the cells were then incubated with the radioactive proteins in supplemented BME.

\section{Reagents}

Human Lf was purified in an iron-free form (ApoLf) from milk, by chromatography on carboxymethyl Sephadex (Querinjean et al, 1971). Human transferrin (Tf) was purchased from Behring Institut, Marburg/Lahn, W Germany.

Lf and Tf were labelled with ${ }^{59} \mathrm{Fe}$ by mixing each protein with ${ }^{59} \mathrm{Fe}$ citrate in the presence of bicarbonate. Labelling of ApoLf and FeLf with ${ }^{125}$ I was done by means of the chloramine-T procedure. The labelled proteins were separated from 
excess radioisotope by filtration through Sephadex G25.

\section{Methods}

After incubation with the radioactive proteins, the cells were successively washed with $2 \mathrm{ml}$ and $1 \mathrm{ml}$ phosphate buffered saline and counted. The cells were extracted with $0.1 \%$ Triton $\mathrm{X}-100$ in distilled water, and the radioactivity was counted. The radioactivity of the wells that were in contact with the labelled proteins in the absence of cells was used as a blank and subtracted from the radioactivity of the cell-containing wells.

\section{Results}

Uptake of ${ }^{59} \mathrm{FeTf}$ and ${ }^{59} \mathrm{FeLf}$ by mouse alveolar macrophages-MAM were incubated with 0.62 $\mathrm{nmol} / \mathrm{ml}$ of ${ }^{59} \mathrm{Fe}$ bound either to Lf or to $\mathrm{Tf}(80 \%$ saturated). The cells were washed twice, and the radioactivity associated with the cells was counted. With Lf, about $2 \times 10^{6}$ atoms of iron were associated with each cell after incubation for $2 \mathrm{~h}$, and $5 \times 10^{8}$ after $20 \mathrm{~h}$. With Tf, a linear uptake was observed reaching a total of $1.2 \times 10^{6}$ atoms of iron per cell after $20 \mathrm{~h}$ (fig 1 ).

Uptake of ${ }^{125} \mathrm{I}-\mathrm{FeLf}$ and ${ }^{125} \mathrm{I}-\mathrm{ApoLf}$-MAM were incubated with ${ }^{125} \mathrm{I}$-labelled FeLf and ApoLf at a concentration of 90 and $84 \mu \mathrm{g} / \mathrm{ml}$ respectively. After $5 \mathrm{~h}$ incubation, about $2.3 \times 10^{6}$ molecules

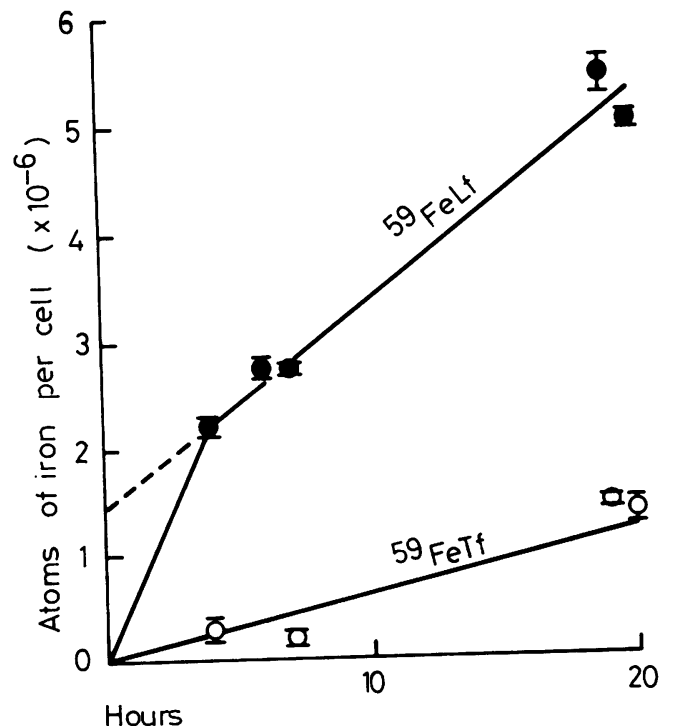

Fig 1 Uptake of $80 \%$ saturated ${ }^{50} \mathrm{FeLf}$ or ${ }^{58} \mathrm{FeTf}$ by MAM as a function of time. Vertical bars represent $1 \mathrm{SD}$. Medium contained $0.62 \mathrm{nmol}^{50} \mathrm{Fe} / \mathrm{ml}$. were bound per cell. In the case of ApoLf this value remained constant over $30 \mathrm{~h}$. In contrast, FeLf bound per cell increased up to $3.6 \times 10^{6}$ molecules per cell after $15 \mathrm{~h}$, and then remained

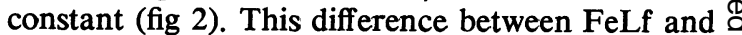
ApoLf was even more evident when the experi- \&

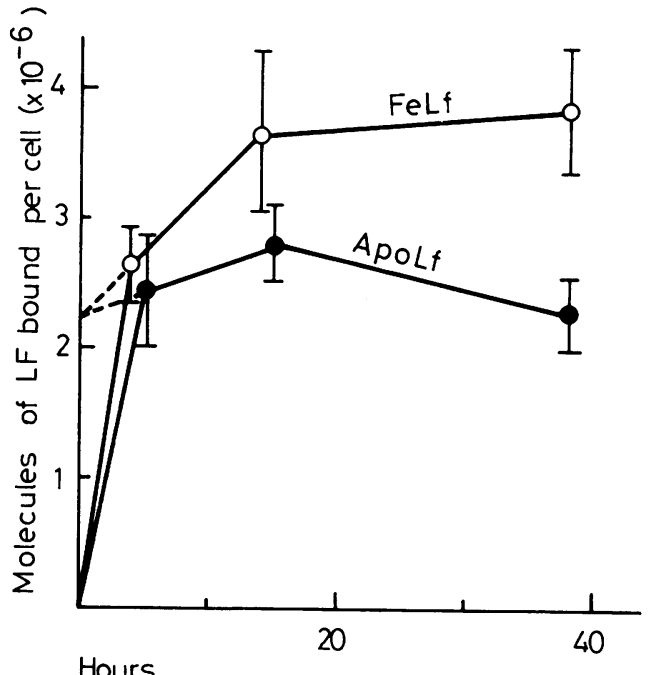

Fig 2 Amounts of ${ }^{125}$ I-labelled FeLf and ApoLf in $M A M$ as a function of time. Concentration of FeLf in culture medium was $90 \mu \mathrm{g} / \mathrm{ml}$. Vertical bars represent $1 S D$.

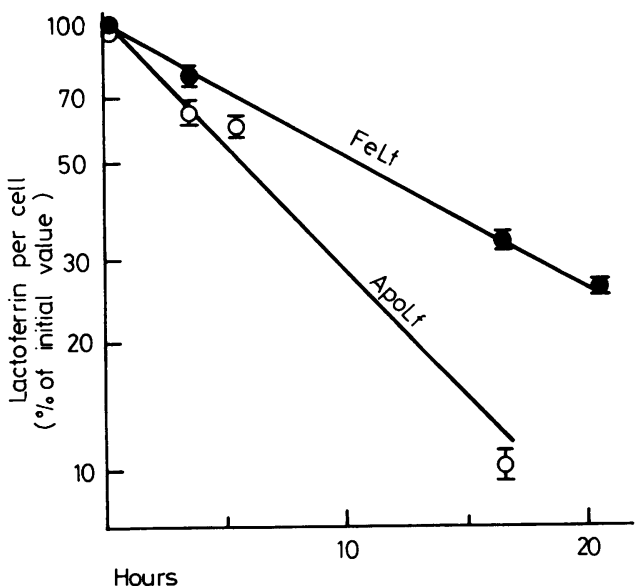

Fig 3 Elimination of FeLf and ApoLf from MAM monitored by decay of radioactivity associated with cells. Cells were incubated with proteins during $48 \mathrm{~h}$, then washed twice and further incubated in medium free of $L f$. 
ments were carried out after stimulation of endocytosis by dextran sulphate $(100 \mu \mathrm{g} / \mathrm{ml})$. In these conditions, after $34 \mathrm{~h}$, about $3.5 \times 10^{6}$ molecules of ApoLf were associated per cell compared with $10.9 \times 10^{6}$ molecules of FeLf.

Half-life of ${ }^{125} I-F e L f$ and ${ }^{125} I-A p o L f$ in MAM -MAM were incubated for $48 \mathrm{~h}$ with ironsaturated and iron-deprived ${ }^{125}$ I-Lf. The cells were then washed with BME containing $10 \%$ FCS and further incubated in a Lf-free medium. The radioactivity associated with the cells decreased exponentially (fig 3 ). The half-life of FeLf $(10.5 \mathrm{~h})$ differed considerably from that of ApoLf $(5 \cdot 8 \mathrm{~h})$.

\section{Discussion}

Previous studies have shown that Lf binds avidly to mouse peritoneal macrophages. Our present work indicates that the same is true for MAM. Extrapolation of the uptake curve of ${ }^{59} \mathrm{FeLf}$ to zero time showed that about $1.5 \times 10^{6}$ atoms of iron (corresponding to $0.93 \times 10^{6}$ molecules of $\mathrm{Lf}$ ) were bound by MAM instantaneously. In the experiments with ${ }^{59} \mathrm{FeTf}$ a similar extrapolation to zero time failed to show such instantaneous binding. It was calculated that MAM picked up per hour about $0.19 \times 10^{6}$ atoms of ${ }^{59} \mathrm{Fe}$ bound to Lf and about $0.07 \times 10^{6}$ atoms of ${ }^{59} \mathrm{Fe}$ bound to $\mathrm{Tf}$ per cell.

When the uptake curves of ${ }^{125}$ I-labelled ApoLf and FeLf were extrapolated to zero time the same amounts of these two forms of Lf were found associated with MAM $\left(2.25 \times 10^{6}\right.$ molecules per cell). This value was obtained at a Lf concentration of $100 \mu \mathrm{g} / \mathrm{ml}$ and correlated well with the value obtained from the ${ }^{59} \mathrm{FeLf}$ uptake experiment using a Lf concentration of $22 \mu \mathrm{g} / \mathrm{ml}$.

The patterns of the uptake curves were similar to those found with peritoneal macrophages. A difference was again seen between ApoLf and FeLf and could be explained by the shorter halflife of ApoLf $(5.8 \mathrm{~h})$ compared to that of FeLf $(20.5 \mathrm{~h})$. It has been shown in the experiments with peritoneal cells that the reduction of radioactivity observed after the cell washing was really caused by digestion and not by shedding from the membrane (Van Snick et al, 1977). The constant parts of the uptake curves corresponded to the balance between the ingestion and elimination of radioactive material.

With FeLf, $6.4 \%$ of the radioactive iodine present in the cell at a given time left the cell after one hour. For ApoLf, the corresponding value was $11 \cdot 3 \%$. From these figures and from the number of molecules of protein bound per cell in the plateau region it was estimated that, with a concentration of $100 \mu \mathrm{g}$ ApoLf or FeLf/ $\mathrm{ml}$ in the medium, $0.27 \times 10^{6}$ molecules of ApoLf and $0.24 \times 10^{6}$ molecules of FeLf enter and leave as degradation products one cell per hour. Like peritoneal macrophages MAM digested ApoLf faster than FeLf, confirming the higher susceptibility of ApoLf to proteolysis (Spik and Montreuil, 1966).

It has been shown that Lf and Tf inhibit the growth of bacteria by removing iron from the medium (Masson et al, 1966b; Bullen et al, 1972). Hence, it is tempting to see, in the binding and endocytosis of $\mathrm{Lf}$ by macrophages, some relationships with the bacteriostatic activity of ApoLf. Two mechanisms could be envisaged. On the one hand, by picking up ApoLf, macrophages would augment their own internal antibacterial activity by lowering the iron level in the phagosomes. On the other hand, the elimination of FeLf by macrophages would prevent the release of metal from the complex after its digestion by proteolytic enzymes present in the secretion. The iron ingested by macrophages via Lf stays within cells in the form of ferritin. No release of iron from peritoneal macrophages was found $45 \mathrm{~h}$ after ingestion of FeLf (Van Snick et al, 1977). It is also noteworthy that the avidity of FeLf for the membrane of peritoneal macrophages is higher than that of ApoLf. FeLf inhibited by $75 \%$ the binding of ApoLf whereas the latter inhibited the binding of FeLf only by $32 \%$ (Van Snick and Masson, 1976). Because of this higher avidity of macrophages for the complex and also the higher digestion rate of ingested ApoLf, the second mechanism leading to iron removal from secretion and sequestration in macrophages seems more likely.

We thank Mr C Richards for correcting this manuscript and Ms V De Chestret for editorial help.

\section{References}

Bullen, J J, Rogers, H J, and Leigh, L (1972). Ironbinding proteins in milk and resistance to Escherichia coli infection in infants. British Medical Journal, 1, 69-75.

Masson, P L, Heremans, J F, and Dive, C (1966a). An iron-binding protein common to many external secretions. Clinica Chimica Acta, 14, 735-739.

Masson, $P$ L, Heremans, J F, Prignot, J J, and Wauters, G (1966b). Immunohistochemical localization and bacteriostatic properties of an ironbinding protein from bronchial mucus. Thorax, 21, 538-544. 
Oram, J D, and Reiter, B (1968). Inhibition of bacteria by lactoferrin and other iron-chelating agents. Biochimica Biophysica Acta, 170, 351-366.

Querinjean, P, Masson, P L, and Heremans, J F (1971). Molecular weight, single-chain structures and amino-acid composition of human lactoferrin. European Journal of Biochemistry, 20, 420-425.

Spik, G, and Montreuil, J (1966). Etudes comparatives de la structure de la transferrine et la lactotransferrine humaines. "Finger printing" des hydrolysats protéasiques des deux glycoprotéides. Comptes rendus des Séances de la Société de biologie, 160, 94-98.
Van Snick, J L, Markowetz, B, and Masson, P L (1977). The ingestion and digestion of human lacto- $O$ ferrin by mouse peritoneal macrophages and the transfer of its iron into ferritin. Journal of Experimental Medicine, 146, 817-827.

Van Snick, J L, and Masson, P L (1976). The binding of human lactoferrin to mouse peritoneal cells. क Journal of Experimental Medicine, 144, 1568-1580.

Requests for reprints to: Dr P L Masson, Unit of Experimental Medicine, UCL-ICP 7430, Avenue Hippocrate, 75-1200 Brussels. 